\title{
New anti-invasive compounds: Results from the Indo-Belgian screening program*
}

\author{
Barbara W. Vanhoecke ${ }^{1}$, Herman T. Depypere ${ }^{1}$, Anicée De Beyter ${ }^{2}$, \\ Sunil K. Sharma ${ }^{3}$, Virinder S. Parmar ${ }^{3}$, Denis De Keukeleire ${ }^{4}$, and \\ Marc E. Bracke $2, \ddagger$ \\ ${ }^{1}$ Department of Gynaecological Oncology, University Hospital, University of Gent, \\ Gent, Belgium; ${ }^{2}$ Laboratory of Experimental Cancerology, University Hospital, \\ University of Gent, Gent, Belgium; ${ }^{3}$ Bioorganic Laboratory, Department of \\ Chemistry, University of Delhi, Delhi -110 007, India; ${ }^{4}$ Laboratory of \\ Pharmacognosy and Phytochemistry, Faculty of Pharmaceutical Sciences, \\ University of Gent, Gent, Belgium
}

\begin{abstract}
The development of anti-invasive and anti-metastatic drugs is a major challenge in current cancer research. A model to study invasion in vitro consisted of organotypic confronting cultures of human MCF-7/6 mammary cancer cells with embryonic chicken heart fragments. Untreated cultures show occupation and destruction of the normal heart fragments within eight days. Inhibition of invasion was observed after addition of the following alkaloids and (poly)phenolics to the culture medium: (+)-catechin, tangeretin, xanthohumol, 3,7-dimethoxyflavone, prenylated chalcones, a pyrazole derivative, an isoxazolylcoumarin, and a prenylated desoxybenzoin. The action targets have been found both in the cancer cells and the surrounding host tissue. We hope that the further characterization of these targets will eventually lead to the development of clinically applicable anti-invasive drugs.
\end{abstract}

\section{INTRODUCTION}

Cancer is the result of a number of genetic mutations that lead to functional alterations. Considering that $80 \%$ of all tumors are derived from epithelia (mammary gland, bronchi, colorectum, prostate, and skin, to cite some of the most frequent origins), cancer cells differ from their normal counterparts in the following aspects [1].

- Growth. By definition, tumors are the result of a higher number of cells, which can be provoked by faster cell proliferation or by slower cell death (apoptosis).

- Differentiation. Cancer cells usually switch to a lower level of cell differentiation and start to express embryonic or fetal markers.

- Tissue integrity. Invasion of cancer cells into the surrounding normal tissues frequently ends up in metastasis.

- Anoikis. Ectopic cell death is one of the mechanisms that prevent normal epithelial cells to survive in a foreign tissue context, such as connective tissue.

\footnotetext{
*Paper based on a presentation at the $24^{\text {th }}$ International Symposium on the Chemistry of Natural Products and the $4^{\text {th }}$ International Congress on Biodiversity, held jointly in Delhi, India, 26-31 January 2004. Other presentations are published in this issue, pp.. 1-344.

¥Corresponding author: Address: Laboratory of Experimental Cancerology, Department of Radiotherapy, Nuclear Medicine and Experimental Cancerology, 1P7 University Hospital De Pintelaan 185, B-9000 Gent, Belgium; Tel.: $32-9$ 240 3007; Fax: 32-9 240 4991; E-mail: brackemarc@hotmail.com
} 
At this point, it is worthwhile to notice that surrounding normal host elements become part of the tumor, and build up together with the cancer cells a micro-ecosystem that eventually governs tumor behavior [2]. These host elements (fibroblasts, immune cells, platelets, and extracellular matrix) secrete or contain molecules that modulate growth, dedifferentiation, invasion, and ectopic survival of the cancer cells. This concept implies that therapeutic targets in oncology are not restricted to the cancer cells per se, but encompass host cells and their extracellular matrix (ECM) as well.

Up to now, cancer treatment has mainly focused on growth reduction. Surgery, radiotherapy, and chemotherapy have all proven to be very effective in tackling tumor volume. Cancer patients, however, usually do not die from growth effects, but from the sequelae of invasion and metastasis. Thus, the oncologist is mainly looking for efficient means to inhibit tumor invasion.

The molecular mechanisms of invasion are not completely understood, but important contributions have been attributed to proteases secreted by the cancer cells, which can degrade the surrounding ECM, to cancer cell motility factors and to factors that disrupt cell-cell adhesion [3,4]. In view of the molecular cross-talks between cancer cells and host cells, receptor signaling through cytoplasmic tyrosine and serine/threonine kinases has been recognized as an important study target in cancer research.

In this overview, we will highlight the three main groups of potentially anti-invasive polyphenolics: catechins, citrus methoxyflavones, and hops (Humulus lupulus L.) components and explain their action mechanisms. Furthermore, we will show how a systematic screening program of polyphenolics and alkaloids from the Laboratory of Bioorganic Chemistry of the University of Delhi in an invasion assay from the Laboratory of Experimental Cancerology of Gent University (Belgium) has led to the discovery of new classes of interesting anti-invasive compounds.

\section{CHICK HEART INVASION ASSAY}

Because the contribution of the host tissue should not be neglected, we have chosen a screening assay based on the confrontation of cancer cells with a fragment of normal tissue [5,6]. Heart tissue fragments are dissected from 9-day-old chicken embryos and precultured to obtain living spheres with a standard diameter of $0.4 \mathrm{~mm}$. These precultured heart fragments (PHFs) are mainly composed of cardiomyocytes, but fibroblasts and endothelial cells are present as well. The extracellular matrix contains laminin, fibronectin, collagen type IV, and collagen type I. These PHFs are confronted with standard aggregates (diameter $0.2 \mathrm{~mm}$ ) of invasive test cells, such as mouse MO4 Ki-ras transformed fetal carcass cells [7] or human MCF-7/6 mammary carcinoma cells [8] (Fig. 1). The aggregates become attached to PHFs by incubation on a semi-solid agar bed overnight and are then transferred as individual pairs into mini-Erlenmeyer flasks for suspension culture in liquid medium. After four (MO4) or eight (MCF-7/6) days of incubation on a gyrotory shaker, the cultures are fixed and embedded for histology. After serial sectioning and staining of the sections with hematoxylin-eosin, the interaction of the tumor cells with the PHF can be reconstructed tri-dimensionally from microscopic analysis of all sections. Although automated image analysis systems are available, the results can be classified satisfactorily along a 5-grades subjective scale. The assay has proved to be relevant to tumor invasion in cancer patients for multiple reasons: invasion is progressive in time and space as it is in natural tumors, the histological pattern of invasion resembles the one observed in the tumor of origin, and the assay discriminates between benign (noninvasive) and malignant (invasive) tumors. It should be admitted, however, that the assay does not cover all aspects of invasion, as it does not take into account the contribution of immune cells. The importance of the latter restriction will be discussed in relation with the effects of the citrus methoxyflavones tangeretin (Table 1, structure 20) and nobiletin (Table 1, structure 22). 


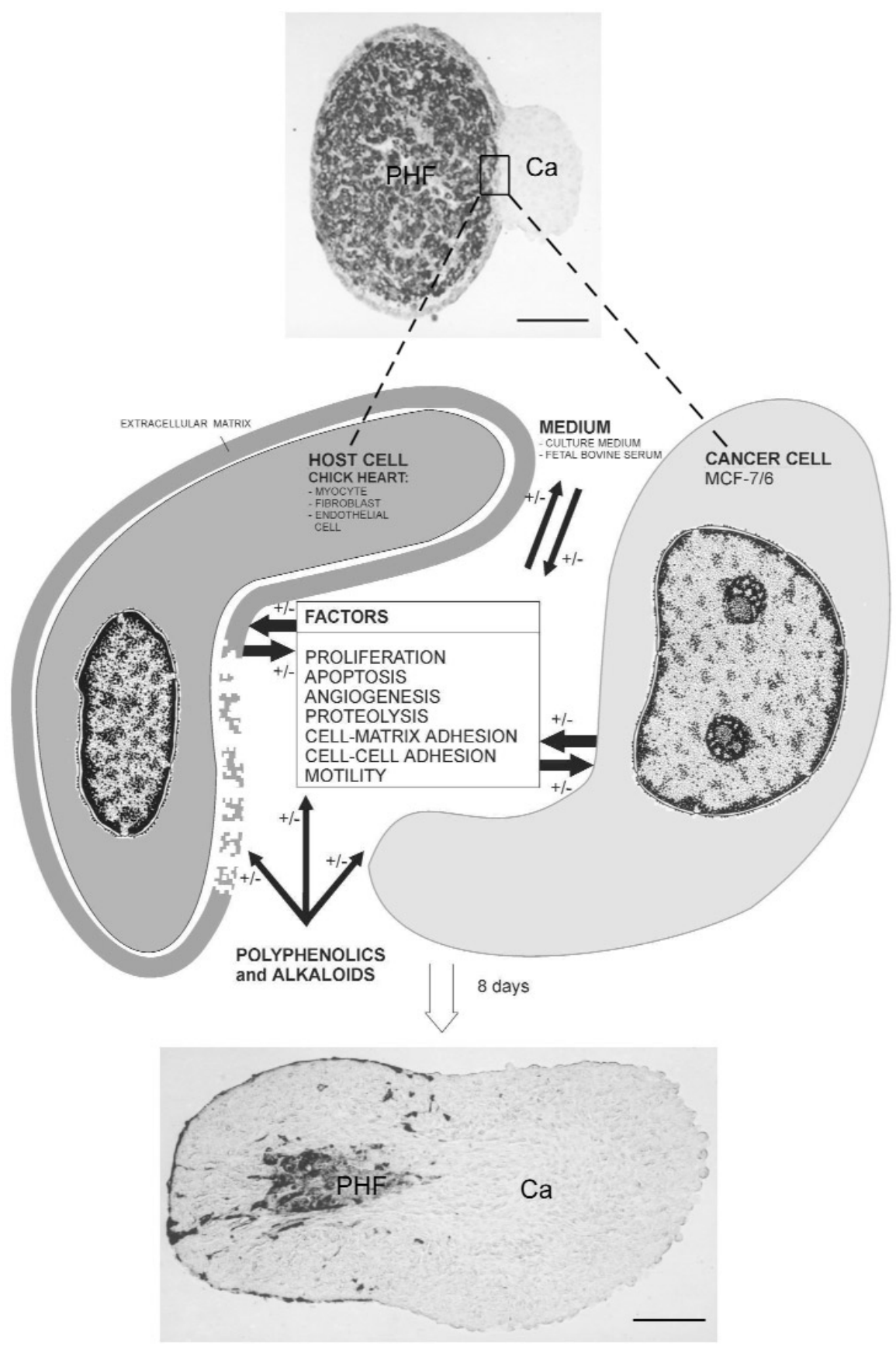

Fig. 1 Molecular cross-talks between cancer and host cells in the chick heart invasion assay. Factors are produced by the cancer cells (MCF-7/6) and the host (myocytes, fibroblasts, endothelial cells, and extracellular matrix) and are present in the culture medium (mainly from fetal bovine serum). These factors affect different activities of both cancer and host cells: proliferation, apoptosis, angiogenesis, proteolysis, cell-matrix adhesion, cell-cell adhesion, and motility. Compounds added to the culture medium including (poly)phenolics and alkaloids can interfere either directly with the cancer and host cells or indirectly via the factors. Invasion is noticed in histological sections from untreated confronting cultures of cancer cell aggregates (Ca) and precultured heart fragments (PHFs): the heart tissue becomes occupied and replaced (invaded) by the cancer cells. 


\section{CATECHINS POSSESS AN ANTI-INVASIVE ACTIVITY DUE TO THEIR INTERACTION WITH LAMININ}

Catechins are flavanols that are present in many plants and trees, and in their extracts such as green teas as well. (+)-Catechin (Fig. 2, structure 1), originally extracted from Uncaria gambir Roxb., inhibited invasion of MO4 and MCF-7/6 cells in the chick heart assay [9]. Its target was not in the cancer cells themselves, but in the ECM of the host tissue, where it was bound to laminin [10]. This molecule is part of the basal lamina that surrounds the myocytes of the chick heart tissue, and treatment with (+)-catechin induced ultrastructural alterations of the heart ECM. Laminin is a large multifunctional glycoprotein with distinct domains that promote cell-matrix adhesion, focal proteolysis of the ECM, and cell motility [11]. Interference with these functions by (+)-catechin led to the formation of a host tissue that became resistant to invasion. Although resistance to invasion had been described for certain tissues such as cartilage, a phenomenon claimed to be due to an anti-invasive factor [12], (+)-catechin was the first compound to show anti-invasive activity through inferring resistance to an otherwise permissive host tissue.<smiles>Oc1cc(O)c2c(c1)O[C@H](c1ccc(O)c(O)c1)C(O)C2</smiles>

3<smiles>COc1cccc(-c2cc(=O)c3ccccc3o2)c1N</smiles>

5<smiles>CCC(=C(c1ccccc1)c1ccccc1)c1ccc(OCCN(C)C)cc1</smiles>

2<smiles>O=c1c(-c2ccc(O)cc2)coc2cc(O)cc(O)c12</smiles>

4<smiles>CC1=C(/C=C/C(C)=C/C=C/C(C)=C/C(=O)O)C(C)(C)CCC1</smiles>

Fig. 2 Structure of (+)-catechin (1), genistein (2), PD 98059 (3), retinoic acid (4), and tamoxifen (5).

\section{METHOXYFLAVONES INHIBIT INVASION BY ACTIVATING THE FUNCTION OF THE E-CADHERIN/CATENIN COMPLEX}

The citrus methoxyflavones, tangeretin (Table 1, structure 20) and nobiletin (Table 1, structure 22) are able to inhibit the invasion of MCF-7/6 cells [13]. Investigation of the molecular target pointed toward the E-cadherin/catenin complex in the MCF-7/6 cells. This complex is present at the plasma membrane of all epithelial cells and is responsible for cell-cell adhesion and functions as a strong invasion suppressor [14]. In cancer cells, the complex is downregulated either by lack of expression or loss of function. In MCF-7/6 cells the complex is expressed, but not functional, thereby allowing invasion to occur. This functional downregulation is amenable to correction by a few compounds such as insulin-like growth factor I, retinoic acid (Fig. 2, structure 4), tamoxifen (Fig. 2, structure 5), and tangeretin [15]. 
Tangeretin treatment leads to more efficient cell-cell adhesion, hence, to invasion suppression. Signal transduction studies recently showed that tangeretin, like another methoxyflavone PD 98059 (Fig. 2, structure 3), is an inhibitor of the mitogen-activated protein kinase (MAPK) pathway, and ongoing research is investigating the relation between the activation status of MAPK and the function of the E-cadherin/catenin complex.

The similar effects and even additive activities of tamoxifen [16], a worldwide prescribed selective estrogen receptor modulator (SERM), and tangeretin in vitro led us to study the effect of a combined tamoxifen plus tangeretin treatment in nude mice bearing MCF-7/6 tumors. When tamoxifen was administered orally to these mice, tumor growth was suppressed as compared to growth in solventtreated mice. However, to our surprise, addition of tangeretin to the drinking water did not potentiate, but counteracted the effect of tamoxifen [17]. Further studies showed that tangeretin inhibited the natural killer cells of the mice and, thus, compromised the immune surveillance of the animals, allowing the MCF-7/6 tumors to grow without restraint. The study illustrates that positive results from the assay in vitro should be checked in animals, since the chick heart does not cover, for instance, immunological aspects of invasion. We want to state explicitly that these experiments do not suggest that breast cancer patients under adjuvant tamoxifen therapy should avoid eating or drinking citrus products, because tangeretin is only present in the peel oil. We consider our data, however, as a warning for such patients that simultaneous intake of tamoxifen with food supplements containing high amounts of citrus methoxyflavones should be avoided.

\section{PRENYLATED CHALCONES FROM HOPS INHIBIT INVASION AND SIGNAL VIA THE MAPK PATHWAY}

Two compounds present in hops (H. lupulus L.) have caught our attention. 8-Prenylnaringenin (called hopein) is currently considered the most potent phytoestrogen in nature (about 200 times more potent than genistein, Fig. 2, structure 2) [18,19]. It activates both $\alpha$ - and $\beta$-estrogen receptors, which can trigger signaling pathways leading to activation of the E-cadherin/catenin complex. In MCF-7/6 cells, 8-prenylnaringenin stimulated, indeed, aggregate formation, but this effect was not strong enough to inhibit invasion in the chick heart assay [20]. Xanthohumol (Table 1, structure 6) was clearly anti-invasive at micromolar concentrations [21,22]. This prenylated chalcone, which is devoid of any estrogenic activity, possesses interesting antithetic effects in the invasion assay. While the mammary cancer cells showed growth inhibition and displayed morphological features of apoptosis, the heart tissue increased its volume and remained histologically unaltered as compared to solvent-treated cultures. We are now studying the possible relationship between these observations and another striking effect of xanthohumol: activation of the MAPK pathway in the cancer cells. We actually consider this activation as an induction mechanism of selective apoptosis in the mammary cancer cells. Since hops extracts are ingredients of the beer brewing process, 8-prenylnaringenin and xanthohumol are present in beer. Their concentrations, however, are so low that, unless these compounds accumulate in certain tissues, it is unlikely that beer drinking can provoke effects that are similar in vivo to what we have observed in models in vitro.

\section{INDO-BELGIAN SCREENING PROGRAM FOR ANTI-INVASIVE COMPOUNDS}

Since 1989, a collaboration between the Universities of Delhi and Gent has been established to screen polyphenolics and alkaloids systematically for their possible anti-invasive activity in the chick heart assay. This has yielded a unique database of many hundreds of compounds and their activities at different concentrations (Table 1). We found anti-invasive activities at $1 \mu \mathrm{M}$ concentrations for a prenylated desoxybenzoin (Table 1, structure 8); an isoflavone (Table 1, structure 9); 3,7-dimethoxyflavone (Table 1, structure 10); chalcones (Table 1, structures 6-7; 11-13); a pyrazole derivative (Table 1, structure 14); an isoxazolylcoumarin (Table 1, structure 15); and a highly methoxylated flavone (Table 1, 
Table 1 Phenolics and alkaloids.

\section{Compounds with anti-invasive activity at $1 \mu \mathrm{M}$.}<smiles>COc1ccc(C=CC(=O)c2c(O)cccc2O)c(O)c1C=CC(C)C</smiles><smiles>CC(C)=CCc1cc(O)ccc1C=Cc1ccccc1</smiles><smiles>CC(C)=CCc1c(O)ccc(C(=O)Cc2ccccc2)c1O</smiles><smiles>O=C1c2ccc(O)cc2OCC1c1ccccc1</smiles><smiles>Cc1ccccc1-c1oc2cc(O)ccc2c(=O)c1O</smiles><smiles>COc1cc(O)c(OCc2ccccc2)c2c1OCCO2</smiles>

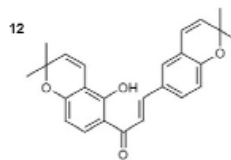

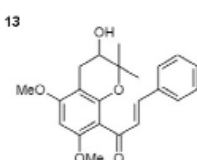<smiles>COc1cccc(C(=O)c2cc(-c3ccc(OC)c(F)c3)n(-c3ccc(F)cc3)n2)c1</smiles><smiles>CCc1ccc(-c2cc(-c3cc4ccccc4oc3=O)on2)cc1</smiles><smiles></smiles>

Compounds with anti-invasive activity at $10 \mu \mathrm{M}$.

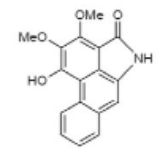

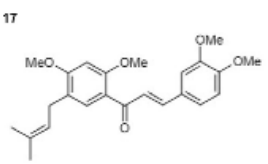<smiles>CC(C)=CCc1cc(C(=O)c2ccccc2)cc(O)c1O</smiles><smiles>CC(C)=CCc1cc(O)cc(O)c1C=Cc1ccc(C(C)C)cc1</smiles>

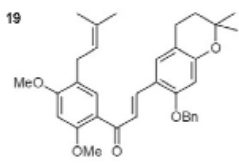<smiles>CC(C)=CCc1cc(C(=O)Cc2ccccc2)c2c(c1O)CCC2</smiles>

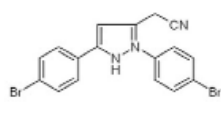<smiles>CCc1cc(-c2ccc(Cl)cc2)[nH]c1-c1ccccc1</smiles><smiles>Cc1ccc(-c2cc(CO)[nH]c2-c2ccc(C)cc2)cc1</smiles><smiles>CCC1C=C(c2ccc(O)cc2)NC1c1ccc(I)cc1</smiles><smiles>CCc1cc(-c2ccc(C)cc2)nn1-c1ccccc1</smiles><smiles>CCc1cc(-c2ccc(C)cc2)nn1-c1ccccc1</smiles><smiles>CCc1ccc(-c2cccc(CCCl)n2)cc1</smiles><smiles></smiles><smiles></smiles><smiles>Cc1ccc(-c2ccc(C(O)c3[nH]ccc3C)[nH]2)cc1</smiles>

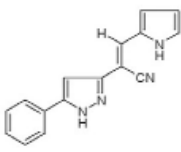

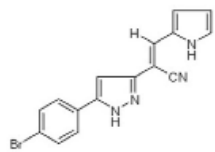

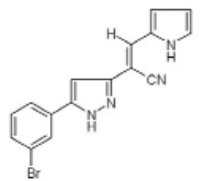

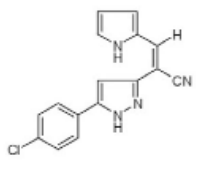<smiles>COc1ccc(C=NC(=O)C(C)=C(C)C2CCC2)cc1</smiles>

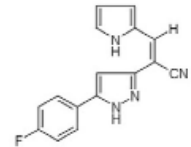

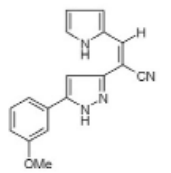

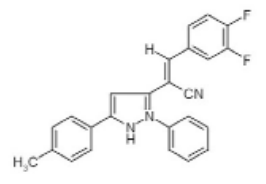

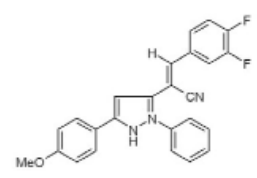

(continues on next page) 
Table 1 (Continued).

\section{Compounds with anti-invasive activity at $10 \mu \mathrm{M}$.}<smiles>Cc1ccc(-c2cc(CN)on2)cc1</smiles><smiles>COCc1cc(-c2ccc(OC)cc2)on1</smiles><smiles>COc1ccc(Cc2c(OC)cc(O)c3c(=O)c(-c4ccccc4)coc23)cc1</smiles><smiles>COc1cc(O)c2c(=O)c(O)c(-c3ccccc3)oc2c1</smiles><smiles></smiles><smiles>CC1(C)Oc2cc(O)c(C(=O)Cc3ccccc3)cc2CC1O</smiles><smiles>COc1cccc(/C=C/C(=O)c2ccc3c(c2)OCO3)c1OC</smiles><smiles>COC1C(=O)C(Cl)=C(Cl)C(=O)C1O</smiles>

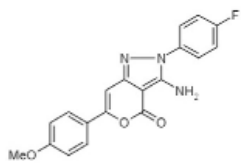<smiles>COc1ccc(-c2cc(=O)c3c(O)cc(OC)cc3o2)cc1</smiles><smiles>COc1cc(O)cc(O)c1-c1cc(=O)cc(-c2ccccc2)o1</smiles><smiles>COc1cc(-c2oc3cc(O)ccc3c(=O)c2O)cc(OC)c1OC</smiles><smiles>COc1ccc(C2CC(=O)c3c(O)cc(O)cc3O2)c(OC)c1</smiles><smiles>COc1ccc(C2CC(=O)c3c(O)cc(OC)cc3O2)c(OC)c1</smiles><smiles>COc1ccc(-c2cc(=O)c3c(O)c(O)c(O)c(O)c3o2)cc1</smiles><smiles>COc1cccc(C=CC(=O)c2cc3c(cc2O)OC(C)(C)CC3O)c1OC</smiles>

Compounds with anti-invasive activity at $100 \mu \mathrm{M}$.<smiles>COc1c(O)c(O)c(O)c(CC=C(C)C)c1O</smiles><smiles>COc1ccc(/C=C/C(=O)c2cc3c(cc2O)CCC(C)(C)O3)cc1OC</smiles><smiles>COc1cc(O)c2c(=O)c(C)c(-c3ccccc3)oc2c1</smiles><smiles></smiles><smiles>O=c1cc(-c2ccccc2)oc2cc(O)cc(O)c12</smiles>

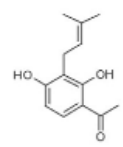<smiles>COc1c(O)cc(O)c(C(=O)/C=C/c2ccccc2)c1O</smiles><smiles>COc1ccc(C(=O)/C=C/c2ccc(C)cc2)cc1OC</smiles><smiles></smiles><smiles>COc1cc(-c2oc3cc(O)ccc3c(=O)c2OC)cc(OC)c1OC</smiles>

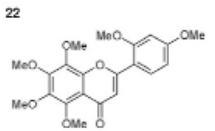<smiles>COc1cc(O)c(-c2c(C)oc3cc(O)cc(O)c3c2=O)c(O)c1</smiles><smiles>COc1ccc(-c2oc3cc(O)cc(O)c3c(=O)c2O)cc1</smiles><smiles>CC(C)=CCc1c(O[N+](=O)[O-])cc(O)c2c1OC(c1ccccc1)CC2=O</smiles>

21<smiles>COc1cc(OC)c(C(=O)C=Cc2ccccc2)c(O)c1CC=C(C)C</smiles><smiles>COc1ccc(/C=C/C(=O)c2ccc3c(c2)OCO3)c(OC)c1</smiles><smiles>COc1ccc(C(CO)C(=O)c2ccc(ON)cc2O)c(O)c1</smiles><smiles>COc1cc(O)c2c(=O)c(OC)c(-c3ccccc3)oc2c1</smiles><smiles></smiles><smiles>COc1ccc(C2COc3c(ccc4occc34)C2=O)cc1</smiles>

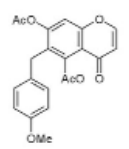

(continues on next page)

(C) 2005 IUPAC, Pure and Applied Chemistry 77, 65-74 
Table 1 (Continued).

\section{Compounds with anti-invasive activity at $100 \mu \mathrm{M}$.}<smiles>COc1ccc2[nH]c3ccc(C)cc3c2c1</smiles><smiles>Cc1cc2c(cc1O)[nH]c1ccccc12</smiles><smiles>CCc1cc(-c2ccc(Cl)cc2)[nH]n1</smiles><smiles></smiles><smiles>Cc1ccc(-c2cc(C)n[nH]2)cc1</smiles><smiles>CCc1cc(-c2ccc(Br)cc2)[nH]n1</smiles><smiles>CCc1ccc(-n2nc(-c3ccc(-c4cccs4)cc3)cc2CC)cc1</smiles><smiles></smiles><smiles>COc1cccc(-c2ccc(-c3ccc(O)cc3)nn2)c1</smiles><smiles>COc1ccc(C=C(C)C2=NC(c3ccc(Cl)cc3)=CC2)cc1</smiles>

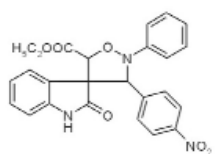<smiles>COC(=O)C1C(NC(=O)c2ccccc2)C(c2ccccc2)N(c2ccccc2)C1c1ccccc1</smiles>

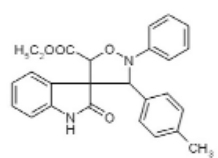

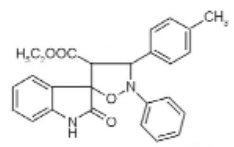<smiles>COC(=O)C1C(C(=O)Nc2ccccc2)C(OC(C)=O)OC(c2ccccc2)N1c1ccccc1</smiles>

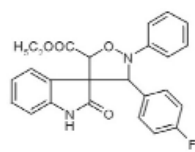<smiles></smiles><smiles>COc1cc(O)c2c(c1)OCC(=O)C2</smiles><smiles>CC(=O)c1oc2ccccc2c1C</smiles><smiles>COC1OC2OC2C1OC</smiles><smiles></smiles><smiles>Nc1onc2cc(-c3ccc(Cl)cc3)oc(=O)c12</smiles><smiles>COc1ccc(C2CC(=O)c3cc4c(cc3O2)OC(C)(C)C(O)C4)c(O)c1</smiles><smiles>C=CCc1cccc2c1OCC2C1COc2ccc(O)cc2C1</smiles><smiles>CCCc1ccc(O)c2c1OCC(c1ccccc1)C2CCC</smiles>

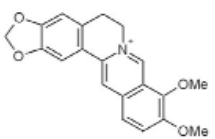<smiles></smiles><smiles>O=C(/C=C/C=C/c1ccc2c(c1)OCO2)N1CCCCC1</smiles><smiles>O=C(OCC1CC2CCC1C2)c1ccccc1</smiles><smiles>Cc1cccc(-c2cc(C)c(O)c(=O)o2)c1</smiles><smiles>Cc1ccc(-c2noc(C)c2C(=O)O)cc1</smiles><smiles></smiles><smiles>COCc1c(C)c2cc(O)c(OC)cc2oc1=O</smiles> 
structure 16). The anti-invasive activity of 3,7-dimethoxyflavone was found at concentrations ranging from 1 to $100 \mu \mathrm{M}$ [23]. At these concentrations, no cytotoxic effects could be detected: the anti-invasive effect was reversible upon removal of the molecule from the medium, while treatment of MCF-7/6 cells or heart fragments did not affect subsequent outgrowth from explants on tissue culture plastic. The molecule did not inhibit growth of MCF-7/6 cell aggregates and, even, increased the volume of PHFs during suspension culture. The action mechanism of 3,7-dimethoxyflavone is not completely clear, but the effects on the volume of the PHFs suggest that the treated heart tissue is the target and becomes resistant to invasion by the cancer cells. Such mechanism resembles the one found for (+)-catechin on invasion.

Anti-invasive activity has been observed for chalcones carrying a prenyl group (Table 1, structures 6-7,17-19,21) $[24,25]$. These compounds were found to inhibit invasion when added to the culture medium at concentrations as low as $1 \mu \mathrm{M}$. For at least three of them, the anti-invasive effect could be associated with a cytotoxic effect on the MCF-7/6 cells, but not on the heart tissue. This selective cytotoxicity was substantiated by different methods, such as histology and growth assays (volume measurements, cell counts, MTT, and sulforhodamine B assays). The anti-invasive effects of the compounds could neither be ascribed to induction of apoptosis nor to promotion of cell-cell adhesion. Selective cytotoxicity for cancer cells is an interesting effect and is actually the rationale for treating cancer patients with tumor necrosis factor. Also, other compounds inhibited invasion at concentrations as low as $1 \mu \mathrm{M}$ [26-28]. Instead of occupying and replacing the heart tissue within eight days, the MCF-7/6 cells grew around the heart fragments and left it intact. At an anti-invasive concentration of $1 \mu \mathrm{M}$, the three compounds did not affect the growth of the MCF-7/6 cells, as shown in the sulforhodamine B assay. Aggregate formation on agar was not stimulated by any of the three anti-invasive compounds, rendering an effect on the E-cadherin/catenin complex unlikely.

\section{CONCLUSION}

Recent cancer research has revealed a number of new targets for therapeutic agents. While growth inhibition was initially the primary goal, other activities of both the cancer cells and the host micro-environment have gained increasing interest. The extensive database generated by the collaborative efforts of the Universities of Delhi (India) and Gent (Belgium), has allowed the selection of alkaloids and (poly)phenolic compounds with potent anti-invasive activities. We hope that the identification of the action targets of these molecules will eventually lead to the development of clinically applicable anti-invasive drugs.

\section{ACKNOWLEDGMENTS}

The authors would like to thank the Department of Citrus of the State of Florida for financial support. Barbara Vanhoecke is recipient of a predoctoral research grant offered by the BOF funding of the Ghent University (No. B/00222/01).

\section{REFERENCES}

1. L. Derycke, V. Van Marck, H. Depypere, M. Bracke. In-Vivo Characterization of Tumors by Means of Nuclear Medicine, C. Van De Wiele, A. Signore, F. De Vos (Eds.), Academic Press, New York (2004). In press.

2. M. Mareel and A. Leroy. Physiol. Rev. 83, 337-376 (2003).

3. W. G. Stetler-Stevenson, S. Aznavoorian, L. A. Liotta. Annu. Rev. Cell Biol. 9, 541-573 (1993).

4. E. Van Aken, O. De Wever, A. S. Correia da Rocha, M. Mareel. Virchows Arch. 439, 725-751 (2001).

5. M. Mareel, J. Kint, C. Meyvisch. Virchows Arch. B Cell Pathol. 30, 95-111 (1979).

(C) 2005 IUPAC, Pure and Applied Chemistry 77, 65-74 
6. M. E. Bracke, T. Boterberg, M. M. Mareel. Methods in Molecular Medicine, Vol. 58: Metastasis Research Protocols, Vol 2: Cell Behavior In Vitro and In Vivo, S. A. Brooks and U. Schumacher (Eds.), pp. 91-102, Humana Press, Totowa, NJ (2001).

7. A. Billiau, H. Sobis, H. Eyssen, H. Van Den Berghe. Arch. Gesamte Virusforsch. 43, 345-351 (1973).

8. H. D. Soule, J. Vazquez, A. Long, S. Albert, M. Brennan. J. Natl. Cancer Inst. 51, 1409-1416 (1973).

9. M. E. Bracke, R. M.-L. Van Cauwenberge, M. M. Mareel. Clin. Exp. Metastasis 2, 161-170 (1984).

10. M. E. Bracke, V. Castronovo, R. M.-L. Van Cauwenberge, L. Vakaet Jr., P. Strojny, J.-M. Foidart, M. M. Mareel. Exp. Cell Res. 173, 193-205 (1987).

11. V. Castronovo. Invasion Metastasis 13, 1-30 (1993).

12. B. U. Pauli, V. A. Memoli, K. E. Kuettner. Cancer Res. 41, 2084-2091 (1981).

13. M. E. Bracke, E. A. Bruyneel, S. J. Vermeulen, K. Vennekens, V. Van Marck, M. M. Mareel. Food Technol. 48, 121-124 (1994).

14. A.-K. Perl, U. Dahl, P. Wilgenbus, H. Cremer, H. Semb, G. Christofori. Nature Med. 5, 286-291 (1999).

15. M. E. Bracke, F. M. Van Roy, M. M. Mareel. Attempts to Understand Metastasis Formation I, U. Günthert and W. Birchmeier (Eds.), pp. 123-161, Springer, Berlin (1996).

16. M. E. Bracke, C. Charlier, E. A. Bruyneel, C. Labit, M. M. Mareel, V. Castronovo. Cancer Res. 54, 4607-4609 (1994).

17. M. E. Bracke, H. T. Depypere, T. Boterberg, V. L. Van Marck, K. M. Vennekens, E. Vanluchene, M. Nuytinck, R. Serreyn, M. M. Mareel. J. Natl. Cancer Inst. 91, 354-359 (1999).

18. S. R. Milligan, J. C. Kalita, A. Heyerick, H. Rong, L. De Cooman, D. De Keukeleire. J. Clin. Endocrinol. Metab. 84, 2249-2252 (1999).

19. S. Milligan, J. Kalita, V. Pocock, A. Heyerick, L. De Cooman, H. Rong, D. De Keukeleire. Reproduction 123, 235-242 (2002).

20. H. Rong, T. Boterberg, J. Maubach, C. Stove, H. Depypere, S. Van Slambrouck, R. Serreyn, D. De Keukeleire, M. Mareel, M. Bracke. Eur. J. Cell Biol. 80, 580-585 (2001).

21. J. F. Stevens, M. Ivancic, V. L. Hsu, M. L. Deinzer. Phytochemistry 44, 1575-1585 (1997).

22. C. Gerhauser, A. Alt, E. Heiss, A. Gamal-Eldeen, K. Klimo, J. Knauft, I. Neumann, H.-R. Scherf, N. Frank, H. Bartsch, H. Becker. Mol. Cancer Ther. 1, 959-969 (2002).

23. V. S. Parmar, R. Jain, S. K. Sharma, A. Vardhan, A. Jha, P. Taneja, S. Singh, B. M. Vyncke, M. E. Bracke, M. M. Mareel. J. Pharm. Sci. 83, 1217-1221 (1994).

24. V. S. Parmar, M. E. Bracke, J. Philippé, J. Wengel, S. C. Jain, C. E. Olsen, K. S. Bisht, N. K. Sharma, A. Courtens, S. K. Sharma, K. Vennekens, V. Van Marck, S. K. Singh, N. Kumar, A. Kumar, S. Malhotra, R. Kumar, V. K. Rajwanshi, R. Jain, M. Mareel. Bioorg. Med. Chem. 5, 1609-1619 (1997).

25. V. S. Parmar, S. C. Jain, K. S. Bisht, N. K. SharmaHimanshu, S. Gupta, A. K. Prasad, A. Jha, Poonam, S. Malhotra, S. K. Sharma, M. E. Bracke, W. Errington, C. E. Olsen, J. Wengel. Ind. J. Chem. 37B, 628-643 (1998).

26. S. Mukherjee, V. Kumar, A. K. Prasad, H. G. Raj, M. E. Bracke, C. E. Olsen, S. C. Jain, V. S. Parmar. Bioorg. Med. Chem. 9, 337-345 (2001).

27. A. Kumar, M. Husain, A. K. Prasad, I. Singh, A. Vats, N. K. Sharma, S. K. Sharma, R. K. Gupta, C. E. Olsen, M. E. Bracke, R. A. Gross, V. S. Parmar. Ind. J. Chem. 42B, 1950-1957 (2003).

28. V. S. Parmar, N. K. Sharma, M. Husain, A. C. Watterson, J. Kumar, L. A. Samuelson, A. L. Cholli, A. K. Prasad, A. Kumar, S. Malhotra, N. Kumar, A. Jha, A. Singh, I. Singh, Himanshu, A. Vats, N. A. Shakil, S. Trikha, S. Mukherjee, S. K. Sharma, S. K. Singh, A. Kumar, H. N. Jha, C. E. Olsen, C. P. Stove, M. E. Bracke, M. M. Mareel. Bioorg. Med. Chem. 11, 913-929 (2003). 